\title{
Study on Characteristics in the Removal Process of Ammonia Nitrogen and Nitrate Nitrogen by an Isolated Heterotrophic Nitrification-Aerobic Denitrification Strain Rhodococcus sp.
}

\author{
Weisi Li ${ }^{*}$ \\ Department of chemical engineering, China University of Petroleum, 266555, Qingdao, China. \\ Email: *top-17@163.com
}

Received 2013

\begin{abstract}
Removal of ammonia nitrogen and nitrate nitrogen by an heterotrophic nitrification-aerobic denitrification strain is an economical and effective method. In this article, a kind of heterotrophic nitrification-aerobic denitrification strain which has aerobic denitrification and heterotrophic nitrification ability was selected, and then was identified as rhodococcus $s p$. by 16S rRNA sequencing analysis and morphological observation. After that, carbon source utilization and nitrificationdenitrification activity of this strain in different $\mathrm{C} / \mathrm{N}$, initial nitrogen concentration were studied. In addition, the assimilation and denitrification activities of ammonia and nitrate were also researched under the condition of nitrate and ammonia coexisted in the solution. The results show that the strain can grow in sodium acetate, glucose, sodium succinate and sodium citrate solutions, and it can not survive in sodium oxalate, sucrose and soluble starch solutions. Initial concentration and $\mathrm{C} / \mathrm{N}$ were important for nitrogen removal rate. This strain can completely remove nitrate/ammonia when nitrate/ammonia concentration was lower than $15 \mathrm{mg} \cdot l^{-1} / 80 \mathrm{mg} \cdot l^{-1}$. the $\mathrm{C} / \mathrm{N}$ of 10 and of 12 were the optimum $\mathrm{C} / \mathrm{N}$ ratio in the nitrate and ammonia removal process respectively. $\mathrm{pH}$ value rose up sharply in the denitrification process and it increased relatively slowly in the nitrification process, which shows that $\mathrm{pH}$ is one of the most important factor inhibiting the denitrification removal process. Nitrite concentration was much higher in denitrification process than in nitrification process. In addition, this strain gave priority to utilizing ammonia as nitrogen source when ammonia and nitrate coexisted in the solution.
\end{abstract}

Keywords: Aerobic Denitrification; Heterotrophic Nitrification; Rhodococcus sp.; Nitrogen Removal

\section{Introduction}

Microbial nitrification and denitrification are totally different biochemical processes according to traditional theory[1]. Nitrification happens only in aerobic condition by two kinds of chemoautotroph bacteria. Ammonia is oxidized to nitrite by nitrosobacteria and then nitrite is oxidized to nitrate by nitrobacterium[2]. Denitrification happens only in anaerobic or facultative aerobic condition. Nitrate and nitrite are reduced to $\mathrm{N}_{2}$ or nitrogen oxides by heterotrophic denitrifying bacteria. However, some bacterium which have heterotrophic nitrification and aerobic denitrification ability were selected in recent 20 years [3-5]. These strains can conduct nitrification and denitrification in aerobic condition using organics as carbon source. Based on this principle, a new nitrogen removal method called simultaneous nitrification and

"Corresponding author. denitrification (SND) is designed and applicated in wastewater treatment process. Comparing with traditional methods, this method has the following advantages: 1) Nitrification and denitrification can conduct in one reaction cell, which saves floor space and money. 2) $\mathrm{pH}$ of water would rise in denitrification process and $\mathrm{OH}^{-}$can neutralize $\mathrm{H}^{+}$generated in nitrification process. 3) Aerobic process is easily controlled and of simple operation. However, these organisms are hard isolated from environment. How to select the special strain is the first problem in nitrogen removal experiments. This work successfully selected a strain which can conduct heterotrophic nitrification and aerobic denitrification. In former research, rhodococcus sp. was lesser studied on nitrogen removal than on desulfurization[6]. In this work, the changing characteristics of $\mathrm{pH}$, nitrate, nitrite, ammonia and growth increment in nitrification or denitrification activity were researched in different $\mathrm{C} / \mathrm{N}$, initial nitrogen 
concentration.

\section{Methods}

\subsection{Microorganism}

Substrate sludge was collected from a river which was polluted by domestic sewage. $0.2 \mathrm{ml}$ supernatant, which was gradient diluted $10^{3}, 10^{4} \ldots 10^{9}$ times by deionized water, was coated BTB medium ${ }^{[7]}$ after being fully shaken up. Then incubate it at $30^{\circ} \mathrm{C}$ for $3 \mathrm{~d}$. The supernatant quality condition was as follows $\left(\mathrm{mg} \cdot \mathrm{l}^{-1}\right)$ : COD, 57 ; TN, 6.33; $\mathrm{NH}_{3}-\mathrm{N}, 0.875 ; \mathrm{NO}_{3}-\mathrm{N}, 4.53 ; \mathrm{DO}, 6$; TP, 0.134; $\mathrm{Cl}^{-}$, 187; $\mathrm{pH}, 8.6$. The BTB medium contained the following $\left(\mathrm{g} \cdot \mathrm{l}^{-1}\right.$ ): bromthymol blue (BTB, dissolved by $0.5 \mathrm{~mL}$ ethyl alcohol), 0.01; agar, 20; $\mathrm{NaNO}_{3}, 1 ; \mathrm{KH}_{2} \mathrm{PO}_{4}, 1 ; \mathrm{NaCl}$, 0.15; $\mathrm{CH}_{3} \mathrm{COONa} \cdot 3 \mathrm{H}_{2} \mathrm{O}, 8 ; \mathrm{pH}, 7.0$. Autoclave all BTB mediums at $121^{\circ} \mathrm{C}$ for $20 \mathrm{~min}$.

Several bacterial strains were observed after three days incubation, then select strains whose BTB medium had changed from green to blue. After that, purify these strains by successive streak transfer on BTB medium. The denitrification ability/nitrification ability of these strains was identified by the aid of LB/HB liquid denitrification medium. After two days growth in LB/HB medium with temperature of $30^{\circ} \mathrm{C}$ and rotating rate of $160 \mathrm{r} / \mathrm{min}$, some nitrite chromogenic reagent was added into the solution. The strain is related to denitrification and nitrification ability if its solution had reddened. The nitrite chromogenic reagent contained the following: 4-aminobenzene sulfonamide, 20 g; N-1-naphthyl ethylenediamine hydrochloride, $1 \mathrm{~g}$; phosphoric acid $50 \mathrm{ml}$; water, $250 \mathrm{ml}$, then dilute them to $500 \mathrm{ml}$. The LB(HB) liquid medium contained the following $\left(\mathrm{g} \cdot \mathrm{l}^{-1}\right): \mathrm{NaNO}_{3}$ $\left(\mathrm{NH}_{4} \mathrm{Cl}\right), 1 ; \mathrm{KH}_{2} \mathrm{PO}_{4}, 1 ; \mathrm{NaCl}, 0.15 ; \mathrm{CH}_{3} \mathrm{COONa} \cdot 3 \mathrm{H}_{2} \mathrm{O}$, 8; $\mathrm{pH}, 7.0-7.3$. Autoclave the medium at $121^{\circ} \mathrm{C}$ for 20 min.

\subsection{S rRNA Gene Sequences, Phylogenetic Analysis and Morphological Observation}

Genomic DNA of isolate HY-1 was extracted using a SK1201-UNIQ-10 column type bacterial DNA Isolation Kit (Sangon, Shanghai, China). The 16S rRNA was amplified by polymerase chain reaction(PCR Thermal Cycler, BBI, Canada) using universal primers (7f, 5'-CAGAGTTTGATCCTGGCT-3' and 1540r(1522), 5'-AGGAGGTGATCCAGCCGCA-3'). The PCR reaction system consisted of: 10pmol of template; $1 \mathrm{ul}$ of primer up $(10 \mathrm{uM})$; $1 \mathrm{ul}$ of primer down $(10 \mathrm{uM}) ; 1 \mathrm{ul}$ of dNTP mix (10 Mm each); 5 ul 10*Taq reaction buffer; 0.25 ul Taq( 5 u/ul) and added water to $50 \mathrm{ul}$. Genes were amplified by pre-denaturation at $98^{\circ} \mathrm{C}$ for $5 \mathrm{~min}$, followed by 35 cycles of denaturation at $95^{\circ} \mathrm{C}$ for $35 \mathrm{~s}$, annealing at $55^{\circ} \mathrm{C}$ for 35 $\mathrm{s}$, and elongation at $72^{\circ} \mathrm{C}$ for $90 \mathrm{~s}$, then by a final of ex- tension at $72^{\circ} \mathrm{C}$ for $8 \mathrm{~min}$. The PCR products were purified and sequencing by a DNA Sequencer (3730, ABI, USA). The closet matching sequences in the GenBank database were searched using the BLAST program and the phylogenetic tree was established by the PHYLIP software. Some fresh HY-1 cells were put on the microslide and dyed by safranine for 1-2min, then observe it by fluorescence convert microscope (LEICA, DMI3000B, Germany). Gram stain method and colony characteristic were also considered.

\subsection{Carbon Source Utilization}

Seven kinds of carbon sources, including sodium acetate, sodium citrate, glucose, soluble starch, sodium oxalate, sucrose and sodium succinate, were used as different substrates in experiments. The carbon source medium contained the following $\left(\mathrm{g} \cdot \mathrm{l}^{-1}\right)$ : $\mathrm{NaNO}_{3}, 1 ; \mathrm{KH}_{2} \mathrm{PO}_{4}, 1$; $\mathrm{NaCl}, 0.15 ; \mathrm{pH}, 7.0-7.3$; C/N (molar ratio), 12; water, $100 \mathrm{ml}$. Autoclave them at $121^{\circ} \mathrm{C}$ for $20 \mathrm{~min}$. Then transfer some HY-1 cells from plate medium into $10 \mathrm{ml}$ aseptic water which was fully shaken up. After that, inoculate $0.5 \mathrm{ml}$ cell suspension into every different carbon source medium. Culture them in the shaking table with stirring rate of $160 \mathrm{r} / \mathrm{min}$ and $30^{\circ} \mathrm{C}$ for two days. Initial values of medium were as follows: $\mathrm{NO}_{3}-\mathrm{N}, 221.3 \mathrm{mg} \cdot \mathrm{l}^{-1}$; $\mathrm{pH}, 7.3 ; \mathrm{NO}_{2}-\mathrm{N}, 0 \mathrm{mg} \cdot \mathrm{l}^{-1}$. Growth condition was observed and nitrate removal rate, nitrite concentration, $\mathrm{OD}_{600}$ (Spectrophotometer, 2100, Unico, USA) and $\mathrm{pH}$ (pH Meter, pH221, HANNA, Italy) were analyzed.

\subsection{Influence of Initial Ammonia and Nitrate Concentration}

The optimum carbon source was set as sodium acetate and original medium of initial nitrate (ammonia) concentration contained the following $\left(\mathrm{mg} \cdot \mathrm{l}^{-1}\right)$ : $\mathrm{NO}_{3}-\mathrm{N}\left(\mathrm{NH}_{3}-\mathrm{N}\right)$, 150 (160.5) ; $\mathrm{KH}_{2} \mathrm{PO}_{4}, 500 ; \mathrm{NaCl}, 150 ; \mathrm{pH}, 7.0-7.3 ; \mathrm{C} / \mathrm{N}$, 36; water, $100 \mathrm{ml}$. Experiment mediums were obtained by diluting the original medium to $1,2,4,8,16,32$ times by deionized water. Then autoclave them at $121^{\circ} \mathrm{C}$ for 20 min. Inoculation and culture methods were the same as section 2.3. Removal rates of nitrate (ammonia), nitrite concentration, $\mathrm{OD}_{600}$ and $\mathrm{pH}$ were analyzed after the mediums were centrifuged with $7000 \mathrm{r} / \mathrm{min}$ for $5 \mathrm{~min}$ (High-Speed Freezing Centrifuge, Allegra 25R, BECKMAN, USA).

\subsection{Effect of $\mathrm{C} / \mathrm{N}$}

The C/N medium contained the following (g. $\left.\mathrm{l}^{-1}\right): \mathrm{KH}_{2} \mathrm{PO}_{4}$, 0.5; NaCl, 0.15; pH, 7.0-7.3; water, 100 ml. Sodium acetate was set as carbon source in the $\mathrm{C} / \mathrm{N}$ experiment. $\mathrm{C} / \mathrm{N}$ was set to a series of $2,4,6,8,10,12,14,16$ and mediums were autoclaved at $121^{\circ} \mathrm{C}$ for $20 \mathrm{~min}$. Inoculation 
and culture methods were the same as section 2.3. Initial nitrate (ammonia) concentration was $50.1 \mathrm{mg} \cdot \mathrm{l}^{-1}$ (79.9 $\mathrm{mg} \cdot \mathrm{l}^{-1}$ ) and initial nitrite concentration was $0 \mathrm{mg} \cdot \mathrm{l}^{-1}$. Final nitrate (ammonia) concentration, nitrite concentration, $\mathrm{OD}_{600}$ and $\mathrm{pH}$ were analyzed after the mediums were centrifuged.

\subsection{Ammonia and Nitrate removal Process of the Strain in the Mixed Solution}

To clarify the competitive utilization of nitrate and ammonia by the strain, a time series experiment was carried out when nitrate and ammonia coexisted in the same solution. The experiment medium contained the following $\left(\mathrm{mg} \cdot \mathrm{l}^{-1}\right.$ ): $\mathrm{NO}_{3}-\mathrm{N}, 48.9 ; \mathrm{NH}_{3}-\mathrm{N}, 77.8 ; \mathrm{KH}_{2} \mathrm{PO}_{4}, 500 ; \mathrm{NaCl}$, 150; $\mathrm{pH}, 7.0-7.3 ; \mathrm{C} / \mathrm{N}, 12$; water, $100 \mathrm{ml}$. Autoclave these mediums at $121^{\circ} \mathrm{C}$ for $20 \mathrm{~min}$. Inoculation and culture methods were the same as section 2.3. Take out one erlenmeyer flask every $2.5 \mathrm{~h}$ and centrifuge the medium. Then measure the nitrate, nitrite, ammonia concentration, $\mathrm{OD}_{600}$ and $\mathrm{pH}$ of the centrifugal liquid.

\section{Results and Discussion}

\subsection{Identification, Phylogenetic Analysis and Morphological Character of the Strain}

HY-1 strain bacterial colony was salmon pink and moist. Under microscope, cells of the strain were rod or coccus, and they exhibited gram positive staining. Rhodococcus $s p$. had these remarkable characteristics. Figure 1 showed the neighbor joining phylogenetic tree using HY-1 gene fragment and GenBank database sequences. HY-1 isolate was most similar (99\%) to Rhodococcus sp. from GenBank database and phylogenetic tree, which coincided with the conclusion of morphological character of the strain. So HY-1 was confirmed to be the strain Rhodococcus sp

\subsection{Carbon Source Utilization by the Strain}

Carbon source[8] and C/N[9-10] are key factors influencing the aerobic denitrification process. The main reason is that periplasmic reductase whose activity was influenced by carbon source was the most important reductase for nitrate removal. In this experiment, the results show that sodium acetate, glucose, sodium succi- nate, sodium citrate can be used by the strain, but sucrose, soluble starch and sodium oxalate can not be used (Table 1). It can be obtained from above result that the strain is inclined to using ionic organic carbon source or small organic molecules. Nitrate removal rate and cell growth increment were higher in ionic organic carbon solution than in glucose solution. Meanwhile, $\mathrm{pH}$ increased much faster in ionic organic carbon solution than in glucose solution. Obviously, low nitrate removal rate is due to strong basicity because alkalinity inhibited the microorganism growth and aerobic denitrification process. Nitrite did not accumulate in all solutions possibly for the reason that nitrite reductase has higher activity than nitrate reductase of HY-1 strain.

Temperature and initial $\mathrm{pH}$ influence cell growth ${ }^{[11]}$ and nitrate removal rate[12]. This strain can survive between $20^{\circ} \mathrm{C}$ and $40^{\circ} \mathrm{C} .30^{\circ} \mathrm{C}$ is the optimum temperature. Initial $\mathrm{pH}$ of between 5 and 9 is suitable for the strain. There was no growth phenomenon when $\mathrm{pH} \leq 4$ or $\mathrm{pH} \geq 10$. Further more, this strain can not grow in anaerobic condition, and it is an absolutely aerobic bacteria.

\subsection{Effect of Initial Nitrate and Ammonia Concentration}

The influence of initial concentration on nitrification and denitrification are briefly discussed as the following aspects : 1) High initial nitrogen concentration or metabolites harm the microbial growth or enzyme activity; 2) Microorganism has the maximum cell density, and the nitrification or denitrification do not occur any more till cell density reaches the maximum. In this denitrification

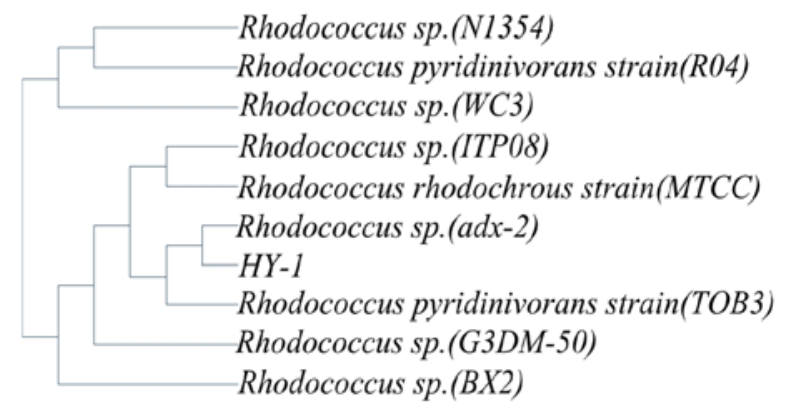

Figure 1. Phylogenetic tree of the strain.

Table 1. Carbon source utilization.

\begin{tabular}{ccccc}
\hline carbon source & Nitrate removal rate & Final $\mathrm{pH}$ & $\mathrm{OD}_{600}$ & Nitrite $\left(\mathrm{mg} \mathrm{l}^{-1}\right)$ \\
\hline sodium acetate & $30.5 \%$ & $9.57 \uparrow$ & 1.87 & 0.002 \\
glucose & $18.7 \%$ & $7.74 \uparrow$ & 1.44 & 0.016 \\
sodium succinate & $27.8 \%$ & $9.54 \uparrow$ & 1.83 & 0.004 \\
sodium citrate & $29.3 \%$ & $9.51 \uparrow$ & 1.86 & 0.008 \\
\hline
\end{tabular}

$\uparrow$ represented $\mathrm{pH}$ rising. 
experiment, $\mathrm{pH}$ reached to about 9.5 and nitrate was not removed completely when nitrate concentration was more than $15 \mathrm{mg} \cdot \mathrm{l}^{-1}$. Obviously, $\mathrm{OH}^{-}$inhibited the denitrification process or enzyme activity. When nitrate concentration was lower than $15 \mathrm{mg} \cdot \mathrm{l}^{-1}$, final $\mathrm{pH}$ did not reach 9.5 and nitrate was completely removed. However, it was surprise that $\mathrm{OD}_{600}$ was proportional to initial nitrate concentration, which illuminated that cells kept growing even when $\mathrm{pH}$ reached 9.5. The possible reason is that this strain had two nitrate metabolic mode. The strain conducts denitrification and it produces $\mathrm{OH}^{-}$when $\mathrm{pH}$ is lower than 9.5. Nitrate is absorbed by the strain only as nitrogen source, and $\mathrm{pH}$ keeps invariant when $\mathrm{pH}$ is higher than 9.5. Nitrite concentration kept low between $0.04 \mathrm{mg} \cdot \mathrm{l}^{-1}$ and $0.17 \mathrm{mg} \cdot \mathrm{l}^{-1}$ in all various initial nitrate concentration solution.

Compared with denitrification, HY-1 strain had higher ammonia removal rate in nitrification. Ammonia removal rate can reach 93\% when initial ammonia concentration was $80 \mathrm{mg} \cdot \mathrm{l}^{-1}$. $\mathrm{pH}$ rose up relatively slow in nitrification process than in denitrification process, which was totally different from $\mathrm{H}^{+}$produced process of autotrophic nitrification.

\subsection{Effect of $\mathrm{C} / \mathrm{N}$}

$\mathrm{C} / \mathrm{N}$ is a key factor influencing on the form and amount of metabolites. In a certain range, the higher the carbon source concentration, the faster the denitrification rate
[9,13,14]. In addition, different $\mathrm{C} / \mathrm{N}$ can result in different biochemical process and metabolites in nitrification and denitrification process, and then it influences on the nitrate (ammonia) removal rate.

From Figure 3 (Left), $\mathrm{pH}$ of all $\mathrm{C} / \mathrm{N}$ solutions rose sharply from about 7.0 to about 9.5. It showed that the denitrification of HY-1 strain is an alkali producing process when carbon source is sodium acetate. Nitrate removal rates rose up at beginning with $\mathrm{C} / \mathrm{N}$ increasing, and then it decreased when $\mathrm{C} / \mathrm{N}>10$. Nitrate removal rate reached the maximum with removal rate of $62.5 \%$ when $\mathrm{C} / \mathrm{N}=10$. Meanwhile, $\mathrm{OD}_{600}$ also got the maximum value when $\mathrm{C} / \mathrm{N}=10$, which illustrated that the strain needed an optimum substrate concentration for growth and removal process. Nitrite did not accumulate in most $\mathrm{C} / \mathrm{N}$ solutions. However,nitrite concentration reached $0.42 \mathrm{mg} \cdot \mathrm{l}^{-1}$ when $\mathrm{C} / \mathrm{N}=10$ and it was much higher than in other $\mathrm{C} / \mathrm{N}$ solutions.

Compared with denitrification (Figure 3, Right), $\mathrm{pH}$ of all $\mathrm{C} / \mathrm{N}$ solutions rose up relatively slow in nitrification process and the highest $\mathrm{pH}$ was 9.47 with a $\mathrm{C} / \mathrm{N}$ of 12. Definitely, final $\mathrm{pH}$ was influenced by $\mathrm{C} / \mathrm{N}$ and carbon source was not sufficient when $\mathrm{C} / \mathrm{N}<12$. In this situation, the higher the $\mathrm{C} / \mathrm{N}$, the higher the ammonia removal rate. Ammonia removal rate exceeded $94 \%$ when $\mathrm{C} / \mathrm{N} \geq 12$. Moreover, $\mathrm{OD}_{600}$ showed similar changes to $\mathrm{pH}$ rising and nitrate removal rate. Nitrite concentration kept very low in all $\mathrm{C} / \mathrm{N}$ solutions.
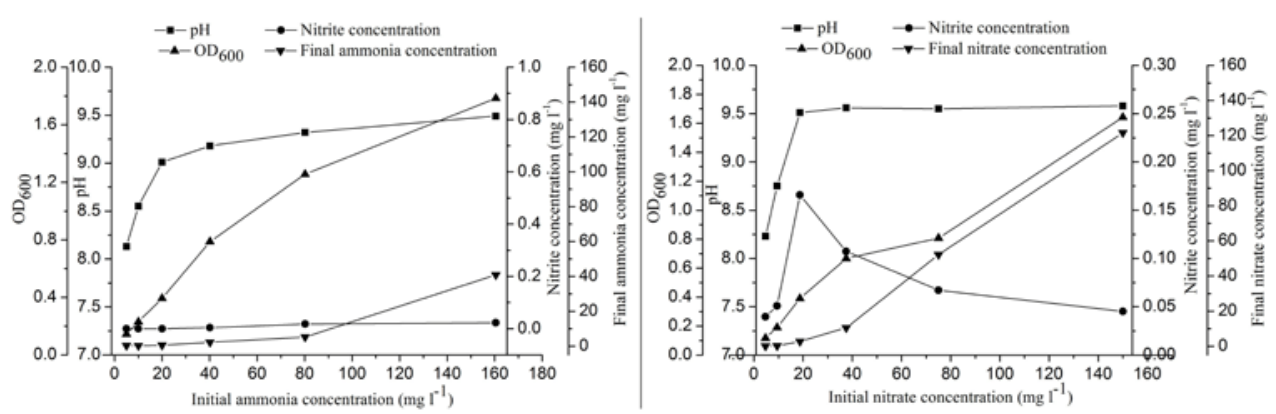

Figure 2. Effect of initial nitrate/ammonia concentration on $\mathrm{pH}$, nitrite and nitrate/ammonia concentration.
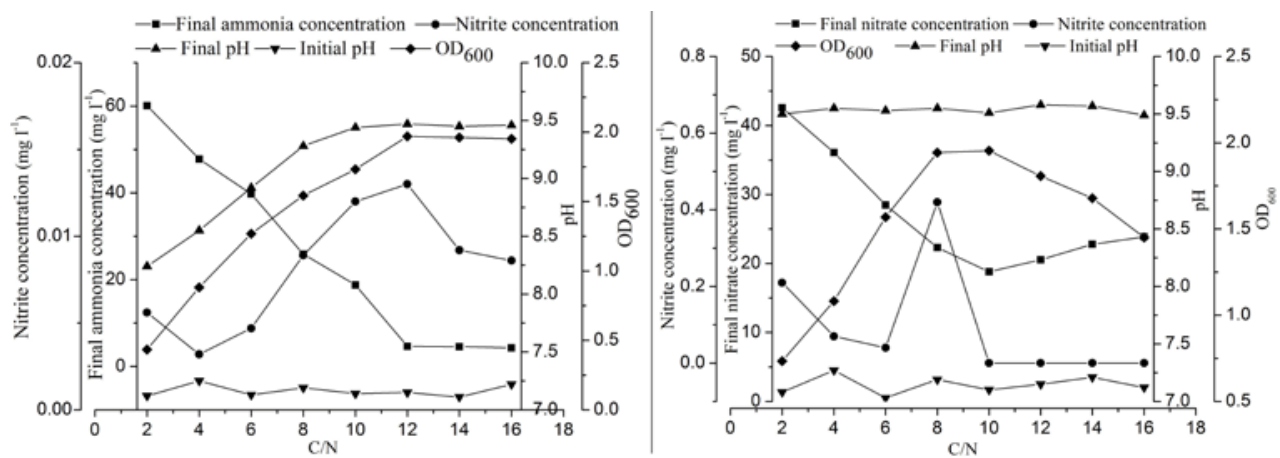

Figure 3. Effect of $\mathrm{C} / \mathrm{N}$ on $\mathrm{pH}$, nitrite and nitrate (ammonia) concentration. 


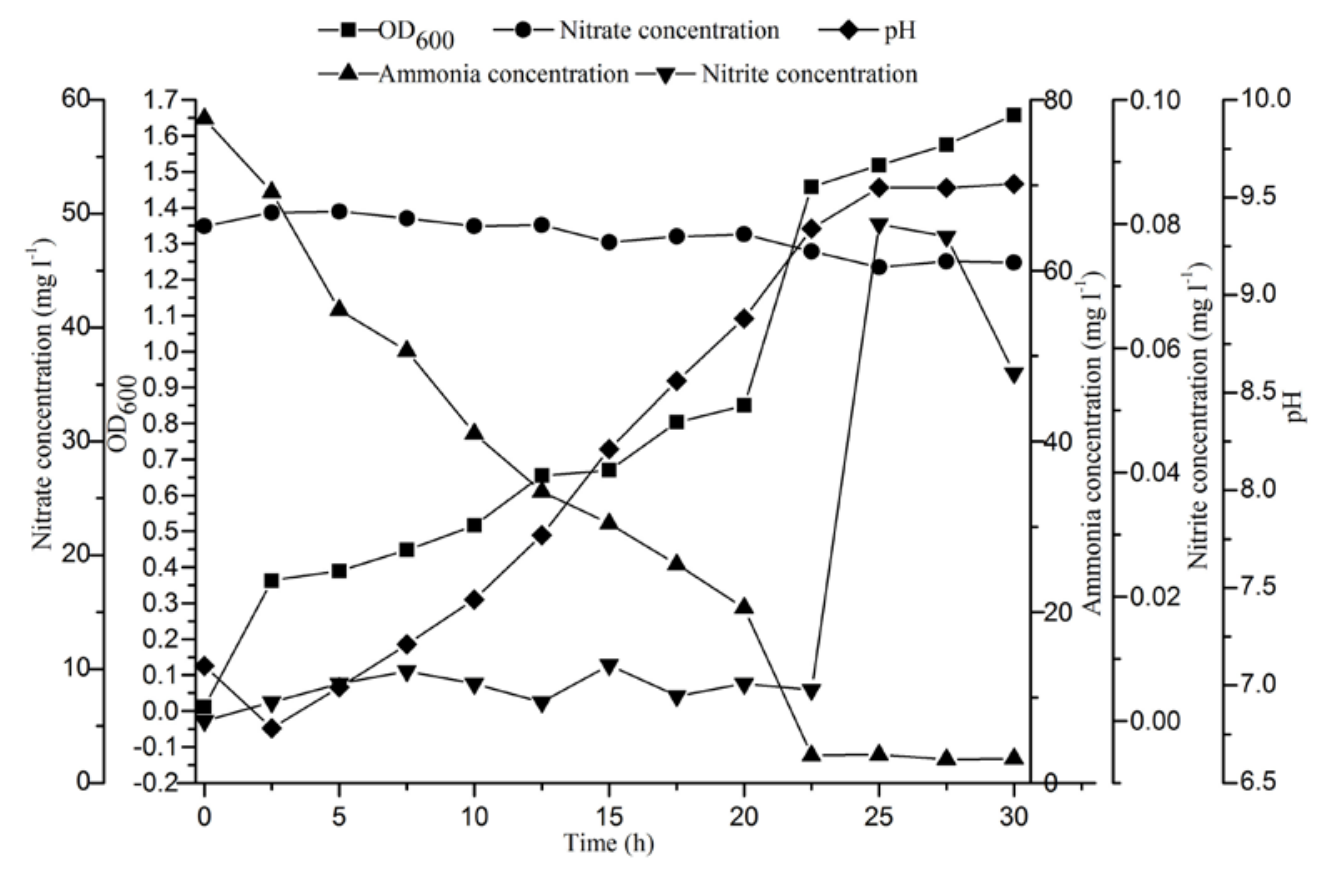

Figure 4. Ammonia and nitrate removal process of the strain in the mixed solution.

\subsection{Ammonia and Nitrate Removal Process of the Strain in the Mixed Solution}

In this experiment (Figure 4), $\mathrm{OD}_{600}$ and ammonia removal rate increased slowly during the beginning $20 \mathrm{~h}$, and then both sharply rose up after $22.5 \mathrm{~h}$. Meantime, ammonia removal rate and $\mathrm{pH}$ also rose up sharply. At this time, the strain was possible in the logarithmic growth phase. Ammonia removal rate increased from $73.6 \%$ of $20^{\text {th }}$ hour to $95.8 \%$ of $22.5^{\text {th }}$ hour. The $\mathrm{pH}$, which increased from 8.88 to 9.34, kept moving on to about 9.55. Nitrate concentration was almost unchanged during beginning $20 \mathrm{~h}$. After $20 \mathrm{~h}$, nitrate concentration decreased lightly, and then reduced from $48.9 \mathrm{mg} \cdot \mathrm{l}^{-1}$ to $45.7 \mathrm{mg} \cdot \mathrm{l}^{-1}$. So the nitrate removal rate was only $6.5 \%$ after $30 \mathrm{~h}$. Obviously, the strain conducted nitrification prior to denitrification when ammonia and nitrate coexisted in the solution. Therefore, ammonia was used firstly by the strain and nitrate was used only when ammonia was completely removed. Nitrite concentration kept a very low level $\left(<0.01 \mathrm{mg} \cdot \mathrm{l}^{-1}\right)$ during the beginning $25 \mathrm{~h}$, and then increased slightly to $0.06 \mathrm{mg} \cdot \mathrm{l}^{-1}$ after $25 \mathrm{~h}$. This phenomenon also showed that denitrification started conducting when ammonia was almost removed.

\section{Conclusions}

This work selected an aerobic heterotrophic nitrificationaerobic denitrification strain which belongs to rhodococcus $s p$.. This strain can use nitrate and ammonia as nitrogen source, and it also can use sodium acetate, glucose, so- dium succinate and sodium citrate as carbon source in denitrification. $15 \mathrm{mg} \cdot \mathrm{l}^{-1}$ and $80 \mathrm{mg} \cdot \mathrm{l}^{-1}$ were the best initial ammonia and nitrate concentration for denitrification and nitrification respectively. A C/N of 10 and a C/N of 12 were the best $\mathrm{C} / \mathrm{N}$ ratio in the nitrate and ammonia removal process respectively. $\mathrm{pH}$ value was the most important factor inhibiting nitrate and ammonia removal process because $\mathrm{pH}$ rose up to a very high value in both processes. In addition, this strain gave priority to utilize ammonia as nitrogen source to nitrate when ammonia and nitrate coexisted in the solution.

\section{REFERENCES}

[1] D. D. Foeht, ,W. Versrtaete. "Biochemical ecology of nitrification and dinirtification”. Adv Microbial Ecol, Vol. 1, No. 5, 1997, pp. 135-214.

[2] B. K. Mobarry, M. Wagner, V. Urbain, B. E. Rittmann and D. A. Stahl. "Phylogenetic probes for analyzing abundance and Special organization of nirtrifying bacteria”. APPI Environ Mierobiol., Vol. 62, No. 6, 1996, pp. 2156-2162.

[3] H. S. Joo, M. Hirai, M. Shodal.“Characteristics of ammonium removal by heterotrophic nitrification-aerobic denitrification by Alcaligenes faecalis No. 4”. J Biosci Bioeng, Vol. 100, No. 2, 2005, pp. 184-191.

[4] J. K. Kim, K. J. Park, K. S. Cho. “Aerobic nitrificationdenitrification by heterotrophic Bacillus strains". Bioresource Technol, Vol. 3, No. 29, 2005, pp. 1897-1906.

[5] P. Mark, D. Dennis. "Focht ${ }^{15} \mathrm{~N}$ kinetic analysis $\mathrm{N}_{2} \mathrm{O}$ production by nirosomonas europaea an examination of nitrifier denitrification”. Applied and Environmental Mi- 
crobiology, Vol. 49, No. 5, 1985, pp. 1134-1141.

[6] C. Gladys, S. Claudia, V. Idania. "Sulfur-selective desulfurization of dibenzothiophene and diesel oil by newly isolated Rhodococcus sp. strains”. FEMS Microbiology Letters, Vol. 215, No. 1, 2002, pp. 157-161.

[7] N. Takaya, A. B. C. S. Maria, S. Yasushi. "Aerobie denitrifieation bacteria that produce low levels of nitrous oxide”. Appl and Environ Mierobiology, Vol. 69, No. 6, 2003, pp. 3152-3157.

[8] D. J. Richardson, S. J. Ferguson. "The influence of carbon substrate on the activity of the periplasmic nitrate reductase in aerobically grown Thiosphaera pantotropha”. Archives of Microbiology, Vol. 157, 1992, pp. 535-537.

[9] M. Kim, S. Jeong, S. J. Yoon. "Aerobic denitrification of Pseudomonas putida $\mathrm{AD}-21$ at different C/N rations". J Biosci Bioeng, Vol. 106, No. 5, 2008, pp. 498-502.

[10] H. K. Huang, S. K. Tseng. "Nitrate reduction by Citro- bacter diversus under aerobic environment”. Applied Microbiology and Biotechnology,Vol. 55, No. 1, 2001, pp. 90-94.

[11] S. K. Gupta, Monak. "Quantitative estmiation of Thiosphaeta pantotropha from aerobic mixed culture". Water Research, Vol. 34, No. 15, 2000, pp. 3765-3768.

[12] G. Mevel, D. Prieur. "Heterotrophic nitrification by a thermophilic Bacillus species as influenced by different culture conditions”. Can J Microbiol, Vol. 46, 2000, pp. 465-473.

[13] J. J. Beun, Van, M. C. M. Loosdrecht, J. J. Heijnen. "Aerobic granulation in sequencing batch airlift reactor". Wat Res, Vol. 36, No. 2, 2002, pp. 702-712.

[14] D. Patureau, N. Bernet, J. P. Delgenes. "Effect of dissolved oxygen and carbon-nitrogen loads on denitrification by an aerobic consortium”. Appl Microbiol Biot, Vol. 54, No. 4, 2000, pp. 535-542. 